Nevada

Environmental

Restoration

Project

Fluid Management Plan for

Corrective Action Unit 447:

Project Shoal Area, Subsurface,

Nevada

Controlled Copy No::

Revision No.: 1

January 2006

Approved for public release; further dissemination unlimited.

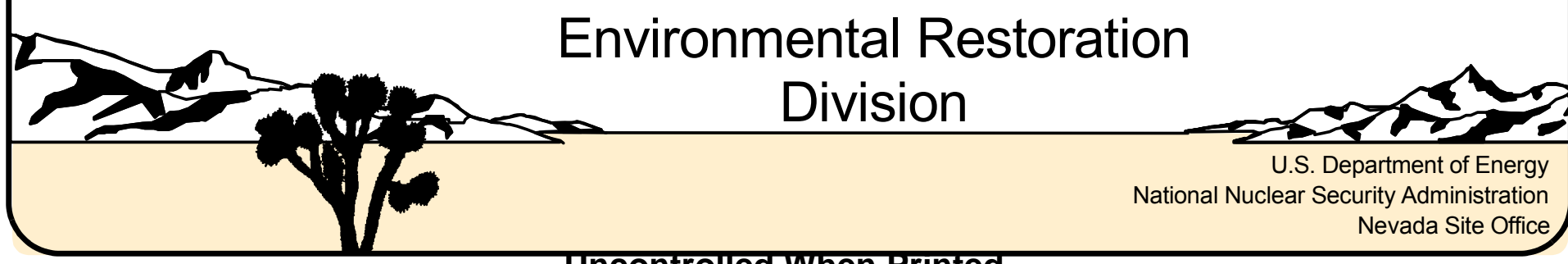


Available for public sale, in paper, from:

U.S. Department of Commerce

National Technical Information Service

5285 Port Royal Road

Springfield, VA 22161

Phone: 800.553 .6847

Fax: 703.605.6900

Email: orders@ntis.gov

Online ordering: http://www.ntis.gov/ordering.htm

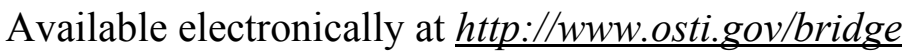

Available for a processing fee to U.S. Department of Energy and its contractors, in paper, from:

\section{U.S. Department of Energy}

Office of Scientific and Technical Information

P.O. Box 62

Oak Ridge, TN 37831-0062

Phone: 865.576 .8401

Fax: 865.576.5728

Email: reports@adonis.osti.gov

Reference herein to any specific commercial product, process, or service by trade name, trademark, manufacturer, or otherwise, does not necessarily constitute or imply its endorsement, recommendation, or favoring by the United States Government or any agency thereof or its contractors or subcontractors. 


\title{
FLUID MANAGEMENT PLAN FOR CORRECTIVE ACTION UNIT 447: PROJECT SHOAL AREA, SUBSURFACE, NEVADA
}

\author{
U.S. Department of Energy \\ National Nuclear Security Administration \\ Nevada Site Office \\ Las Vegas, Nevada
}

Controlled Copy No.:

Revision No.: 1

January 2006

Approved for public release; further dissemination unlimited. 


\section{FLUID MANAGEMENT PLAN FOR \\ CORRECTIVE ACTION UNIT 447: \\ PROJECT SHOAL AREA, SUBSURFACE, NEVADA}

Approved by: APPROVED SIGNATURE

Date: $1 / 31 / 2006$

John B. Jones, Acting Project Manager

Offsites Project

\footnotetext{
Approved by: APPROVED SIGNATURE

Date: $1 / 31 / 2006$

Janet Appenzeller-Wing, Acting Division Director

Environmental Restoration Division
} 


\section{Table of Contents}

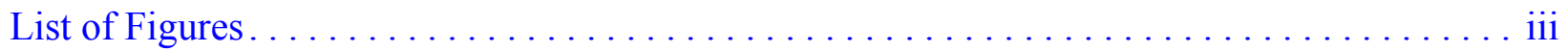

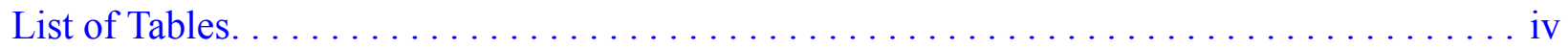

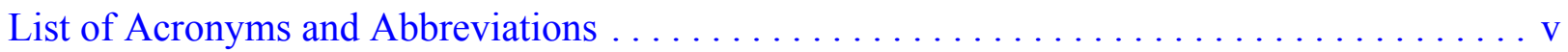

Definitions ................................................ vi

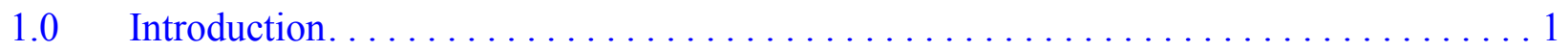



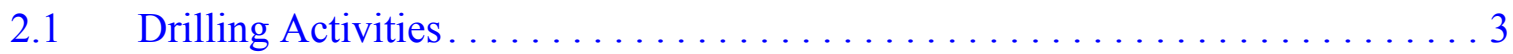

$2.2 \quad$ Other Well-Site Activities . . . . . . . . . . . . . . . . . . . . . . . . . 3

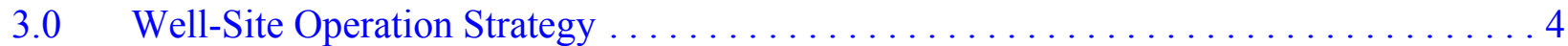

$4.0 \quad$ Near-Field Fluid Management Strategy $\ldots \ldots \ldots \ldots \ldots \ldots \ldots \ldots \ldots \ldots \ldots \ldots \ldots \ldots \ldots \ldots$

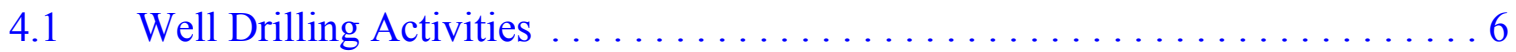

4.1.1 Fluid Containment ........................... 6

4.1.2 Monitoring Program........................

4.1.2.1 Monitoring ...................... 10

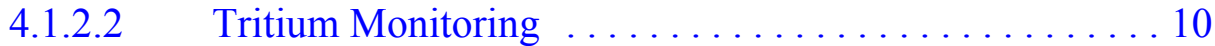

4.1.2.3 Lead Monitoring ..................... 10

4.1.3 Fluid Management Decision Criteria . . . . . . . . . . . . . . . 11

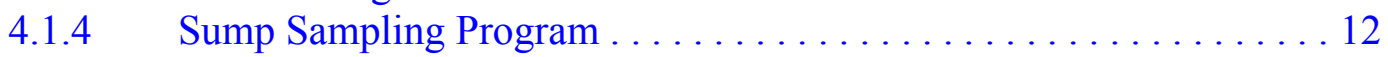

4.1.5 Fluid Disposition .............................. 15

$4.2 \quad$ Other Well-Site Activities . . . . . . . . . . . . . . . . . . . . . . . . 16

4.2.1 Fluid Containment ........................... 18

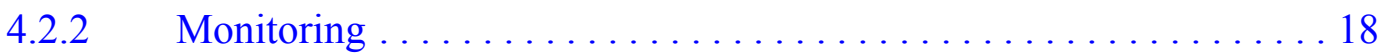

4.2.3 Fluid Management Decision Criteria .................. 18

4.2.4 Sump Sampling Program .......................... 18

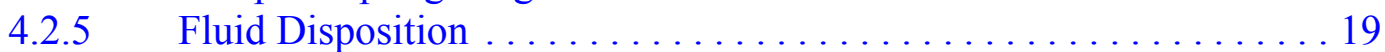

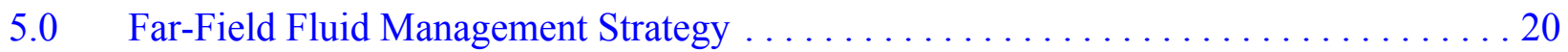

$5.1 \quad$ Well Drilling Activities . . . . . . . . . . . . . . . . . . . . . 20

$5.1 .1 \quad$ Fluid Containment ............................ 20

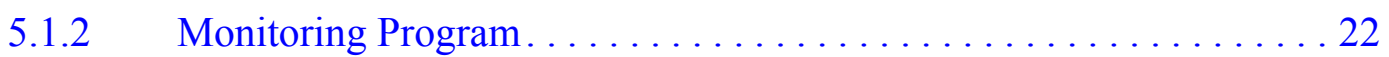

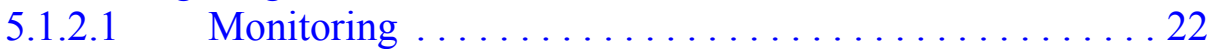

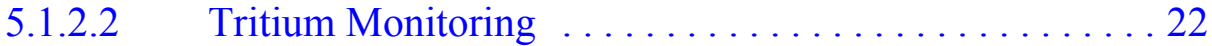

$5.2 \quad$ Other Well-Site Activities . . . . . . . . . . . . . . . . . . . . . . . . . . . . . 24

5.2.1 Fluid Containment .............................. 24

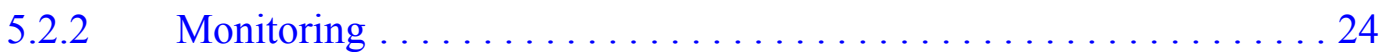

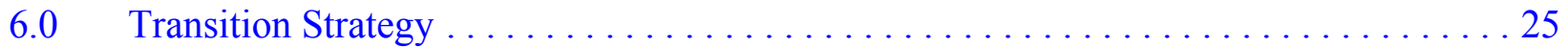




\section{Table of Contents (Continued)}

$7.0 \quad$ Reporting Requirements . . . . . . . . . . . . . . . 26

$8.0 \quad$ References. . . . . . . . . . . . . . . . . . . . . . . . . . . . . . . 28

Appendix A - NDEP Comments 


\section{List of Figures}

Number

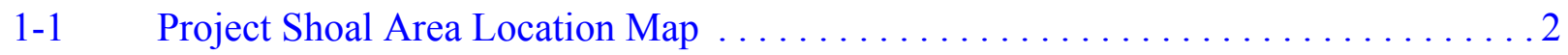

3-1 Fluid Management Planning Process $\ldots \ldots \ldots \ldots \ldots \ldots \ldots \ldots \ldots \ldots$

$4-1 \quad$ Near-Field Site Layout $\ldots \ldots \ldots \ldots \ldots \ldots \ldots \ldots \ldots \ldots \ldots \ldots \ldots$

4-2 Near-Field Monitoring Decision Diagram . . . . . . . . . . . . . . . 9

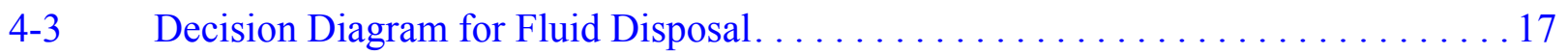

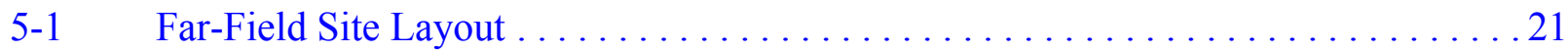

$5-2 \quad$ Far-Field Monitoring Decision Diagram $\ldots \ldots \ldots \ldots \ldots \ldots \ldots \ldots \ldots \ldots \ldots$ 


\section{List of Tables}

Number

4-1 Fluid Management Decision Criteria Limits ..................... 12

4-2 Analytical Laboratory Requirements for Fluid Management Samples ........ 13 


\section{List of Acronyms and Abbreviations}

${ }^{\circ} \mathrm{C} \quad$ Degrees Celsius

BoFF Bureau of Federal Facilities

CAU Corrective Action Unit

CFR Code of Federal Regulations

DOE U.S. Department of Energy

FFACO Federal Facility Agreement and Consent Order

FMP Fluid Management Plan

$\mathrm{mg} / \mathrm{L} \quad$ Milligrams per liter

N/A Not applicable

NDEP Nevada Division of Environmental Protection

NDWS Nevada Drinking Water Standards

NNSA/NSO U.S. Department of Energy, National Nuclear Security Administration Nevada Site Office

NTS Nevada Test Site

$\mathrm{pCi} / \mathrm{L} \quad$ Picocuries per liter

PSA Project Shoal Area

RCRA Resource Conservation and Recovery Act 


\section{Definitions}

Containment - A structure made of earthen materials or fabricated from metal or other suitable material that is designed to contain fluids generated from well-site activities. Typical containment structures identified in this plan are unlined sumps, lined sumps, infiltration basins, and tanks.

Discharge - The release of fluids for final disposition. Fluids discharged for disposal purposes must meet applicable fluid management criteria (e.g., the Nevada Drinking Water Standards [NDWS] for discharge to an infiltration basin/area or less than the NDWS for discharge to the ground surface). Discharge also describes the physical process whereby fluids are released from the "flow line or discharge line" during drilling operations. Drilling discharges are typically routed to appropriate containment structures (e.g., lined sump, infiltration basin prior to final disposal).

Disposal - The act of discharging fluids with no intention of further management. On-site disposal options include discharge to an infiltration basin/area or the ground surface and evaporation in lined sumps.

Ground Surface - The natural relatively undisturbed condition of an area of soil or bedrock. Dry washes, intermittent stream beds, or other natural depressions identified by the Nevada Division of Environmental Protection as waters of the state are not included in this definition.

Infiltration Basin - An engineered, constructed, earthen structure designed for the storage and infiltration of well fluids meeting applicable fluid management criteria.

Infiltration Area - An area of the ground surface with defined boundaries that has been designated for the purpose of discharge and infiltration of well fluids meeting applicable fluid management criteria.

Lined Sump - An engineered, constructed earthen structure designed for the storage of well fluids that may exceed applicable fluid management criteria. Sump construction includes the placement of an appropriate liner material to ensure containment of the fluids and solids. 


\section{Definitions (Continued)}

Transfer - The physical transfer of well-derived fluids from one appropriate fluid containment structure to another containment structure. Fluids may be conveyed using mechanical means or gravity means through appropriate piping or hoses.

Unlined Sump - An engineered, constructed, earthen structure designed for the storage and infiltration of well fluids meeting applicable fluid management criteria. Sump construction may accommodate the introduction of a liner, if required, as part of the specific well-site operational strategy. 


\subsection{Introduction}

The U.S. Department of Energy (DOE), National Nuclear Security Administration Nevada Site Office (NNSA/NSO) initiated the Offsites Project to characterize the risk posed to human health and the environment as a result of testing at formerly used nuclear sites in Alaska, Colorado, Mississippi, Nevada, and New Mexico. The scope of this Fluid Management Plan (FMP) is to support the subsurface investigation at the Project Shoal Area (PSA) Corrective Action Unit (CAU) 447, Shoal Subsurface, Nevada, in accordance with the Federal Facility Agreement and Consent Order (FFACO) (1996). Corrective Action Unit 447 is located in the Sand Spring Range, south of Highway 50, about 39 miles southeast of Fallon, Nevada. (Figure 1-1).

\section{Scope}

This FMP will be used at the PSA in lieu of an individual discharge permit for each well or a general water pollution control permit for management of all fluids produced during the drilling, construction, development, testing, experimentation, and/or sampling of wells conducted by the Offsites Project. The FMP provides guidance for the management of fluids generated during investigation activities and provides the standards by which fluids may be discharged on site. Although the Nevada Division of Environmental Protection (NDEP), Bureau of Federal Facilities (BoFF) is not a signatory to this FMP, it is involved in the negotiation of the contents of this plan and approves the conditions contained within.

The major elements of this FMP include: (1) establishment of a well-site operations strategy; (2) site design/layout; (3) monitoring of contamination indicators (monitoring program); (4) sump characterization (sump sampling program); (5) fluid management decision criteria and fluid disposition; and (6) reporting requirements. 


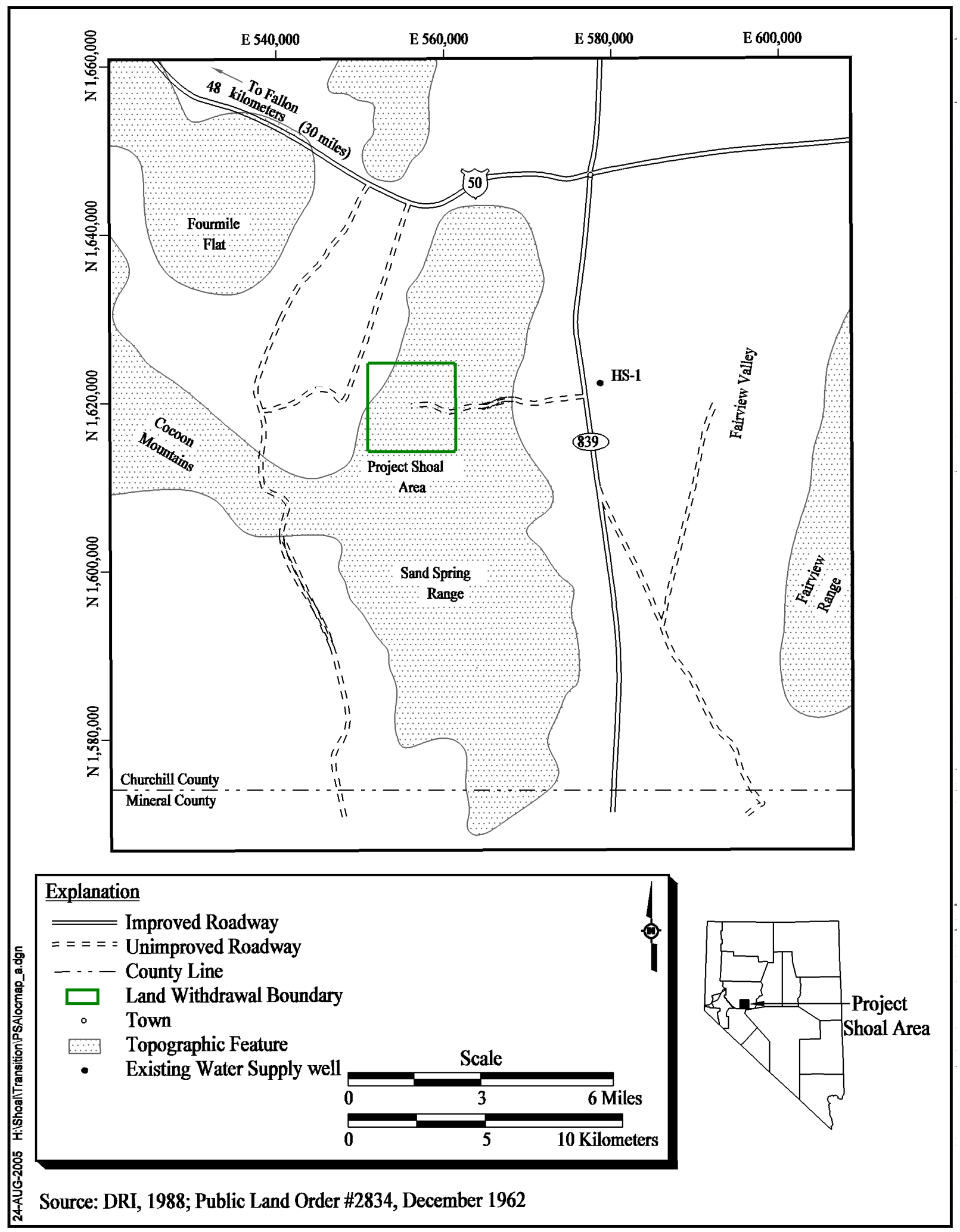

Figure 1-1

Project Shoal Area Location Map 


\subsection{Proposed Investigation}

This FMP serves as the governing document for all fluid-producing activities conducted in support of Offsites Project investigations at PSA. For the purpose of this FMP, investigation activities are considered either (1) drilling activities that advance the borehole, or (2) other well-site activities.

\subsection{Drilling Activities}

Drilling activities that advance the borehole involve only those that cut or disturb new subsurface formation(s). Presumably, groundwater and rock cuttings generated as part of these operations are from geologic formations that are uncharacterized with regard to their chemical and radiological nature. Occasionally, well recompletion may involve cutting into new subsurface formations.

\subsection{Other Well-Site Activities}

Other well-site activities include those which encounter subsurface formations that were previously drilled through or contacted in some way. Examples of other well-site activities that typically occur without advancement of the borehole include cleaning and conditioning the borehole, circulation of the borehole, fishing and wash-over operations, well completion operations such as casing and stemming of annular materials, well development, testing, and periodic sampling events. Well completion designs and associated well construction activities will vary depending on well-specific objectives. The activities may include the setting of the immediate casing; the running of a completion string to a specified depth; and/or the isolation of productive zones with gravel, cement, packers, and sliding sleeves. Other activities may be conducted within a discrete time period (e.g., a one-day well sampling event) or over a span of time (e.g., a series of well purging and testing activities that spans months). Many of the wells drilled or recompleted under the Offsites Project may support long-term monitoring programs and may be sampled periodically. Typically, well sampling involves purging the well for a period of time during which fluids are produced. The volume of fluids produced will vary from well to well. 


\subsection{Well-Site Operation Strategy}

Figure 3-1 outlines the process to be followed in preparing for a fluid-producing investigation activity under this FMP. This process shall be completed before the investigation activity begins. The first step in the process is to establish the well location(s). The well-site operation strategy is then determined. The well-site operation strategy is site-specific and will vary based on the available historical knowledge of the site and on the scientific and technical objectives of the investigation. Such a strategy is designed with fluid production and the potential for encountering contamination in mind. The well-site operation strategy dictates the type of containment required for the operation and the initial monitoring requirements.



Figure 3-1

Fluid Management Planning Process 
There are two basic well-site operation strategies employed under this FMP: near-field and far-field. The near- and far-field designations refer to the potential for encountering radioactive contamination in the well. A comprehensive assessment of historical information (or "process knowledge") that may be relevant to the site operation strategy must be conducted. Information to be used in support of this decision may include, but shall not be limited to, the following:

- Proximity of the proposed well(s) to the location of the underground nuclear detonation.

- Hydrogeologic setting of the proposed well and surrounding areas.

- The potential for chemical or radiological contamination in the groundwater due to the underground test.

- Documentation or interviews pertaining to historical site operations.

- Analytical and/or site monitoring data associated with the well or surrounding area wells.

- Groundwater flow and transport modeling results.

- Other applicable process/historical knowledge.

Once the initial well-site operation strategy is determined and the nature of fluid containment (e.g., lined sumps, infiltration basins/areas) to be located at the site is identified, the NNSA/NSO shall notify NDEP, as indicated in Figure 3-1. Such notification shall include the well-site operation strategy and supporting rationale as well as specifics pertaining to the nature and configuration of the fluid containment to be located at the site(s). This written notification shall be submitted to NDEP for approval at the address noted in Section 7.0.

The initial operation strategy for a particular well site will be applied to all subsequent well-site activities, such as aquifer tests or routine sampling, unless site process knowledge or other site factors change. For example, if a well were drilled under a near-field strategy and site conditions continue to support this determination, subsequent investigation activities must proceed under a near-field strategy, unless an alternate strategy can be justified. If the NNSA/NSO plans to operate a particular investigation activity using a different strategy than that initially determined for the well site, the NNSA/NSO shall notify the NDEP. Such notification may be provided via telephone, fax, or e-mail and will be followed by a formal letter describing any approved operational changes. 


\subsection{Near-Field Fluid Management Strategy}

Because contaminated fluids are more likely to be encountered at a near-field well, the fluid management strategy must provide reasonable assurance that fluids produced at these wells will be managed in compliance with applicable state and federal regulations. The near-field strategy involves the use of analysis of contaminant indicators (tritium and lead) through monitoring and the containment of fluids in sumps.

For the purpose of operation strategy implementation, investigation activities are considered either (1) activities that advance the borehole as part of drilling operations, or (2) other well-site activities.

\subsection{Well Drilling Activities}

Drilling activities that advance the borehole involve only those that cut or disturb new subsurface formation(s). Presumably, groundwater and rock cuttings generated as part of these operations are from geologic formations that are uncharacterized with regard to their chemical and radiological nature.

\subsubsection{Fluid Containment}

Fluid containment under a near-field strategy will be identified in the NNSA/NSO Well-Site Operation Strategy letter. Sump construction and use decisions will be based in part on predicted fluid volumes and the potential for radiological and/or chemical contamination in the well. Direct discharge of fluids to the ground surface or to an infiltration basin/area at a near-field well site is generally not anticipated; however, this practice may be approved on a case-by-case basis as identified in the Well-Site Operation Strategy letter and approved by the NDEP.

Figure 4-1 provides a typical fluid containment configuration for a well site operating under a near-field strategy. Site-specific characteristics and restrictions will determine the actual site layout. An anticipated layout shall be provided in the Well-Site Operation Strategy letter. 


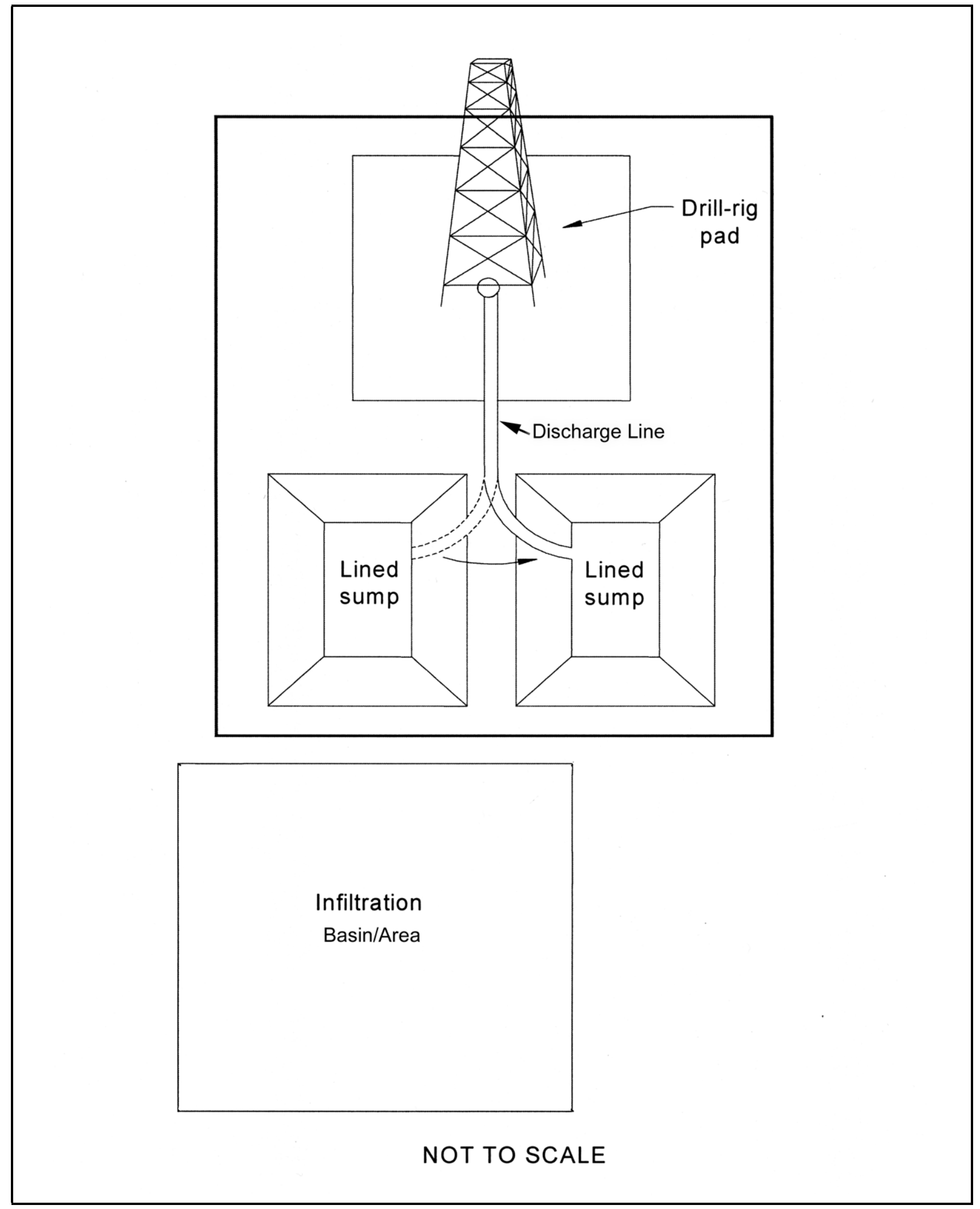

Figure 4-1

Near-Field Site Layout 
Following is an example of a near-field sump construction and use scenario. This scenario may be considered generally applicable to the given site conditions; however, actual sump construction and use may vary among well sites.

In a near-field scenario, two lined sumps may be constructed, with drilling fluids discharged to the first sump until that point when radiological or chemical contamination is encountered in the well. Once fluids exceed applicable FMP criteria, fluids are diverted to the second sump. A sample is then collected from the first sump and analyzed at a laboratory for FMP parameters (see Section 4.1.2.1). The comparison of sample results with FMP criteria will dictate whether the fluids from the first sump may be discharged directly to an infiltration basin/area, discharged to the ground surface, or contained. When filled, the fluid volume in the second sump will undergo the same procedure.

\subsubsection{Monitoring Program}

The monitoring program supports the daily management of fluids produced during an investigation activity. This program is based on the use of the contamination indicators, tritium and/or lead, to make decisions regarding fluid containment and/or the progression of investigation operations. Such decisions are based on analysis that is performed while operations proceed. Based on its physical and chemical properties, tritium has been chosen as the indicator for radioactive contamination. Tritium is a radioactive isotope that is readily transported in groundwater. Tritium provides the earliest detection of groundwater contamination resulting from underground testing. Lead has been chosen as the indicator for chemical contamination in groundwater at near-field designated well sites. This is because lead-laden "racks" were commonly used in the design and construction of underground nuclear tests and lead was also used as shielding in the design of some underground nuclear devices. Either of these sources may have contributed to lead contamination in groundwater.

Figure 4-2 outlines the decision points in the monitoring program for near-field well sites under this FMP. Monitoring results are not typically used to support final fluid disposition decisions; rather, monitoring results prompt daily operational decisions. For example, in a near-field scenario, the tritium action level of 20,000 picocuries per liter (pCi/L) (the Nevada Drinking Water Standards [NDWS]) would prompt the diversion of fluids to a lined sump. The lead action level of 3 milligrams per liter $(\mathrm{mg} / \mathrm{L})$ indicates when fluid lead concentrations are approaching the Resource Conservation 


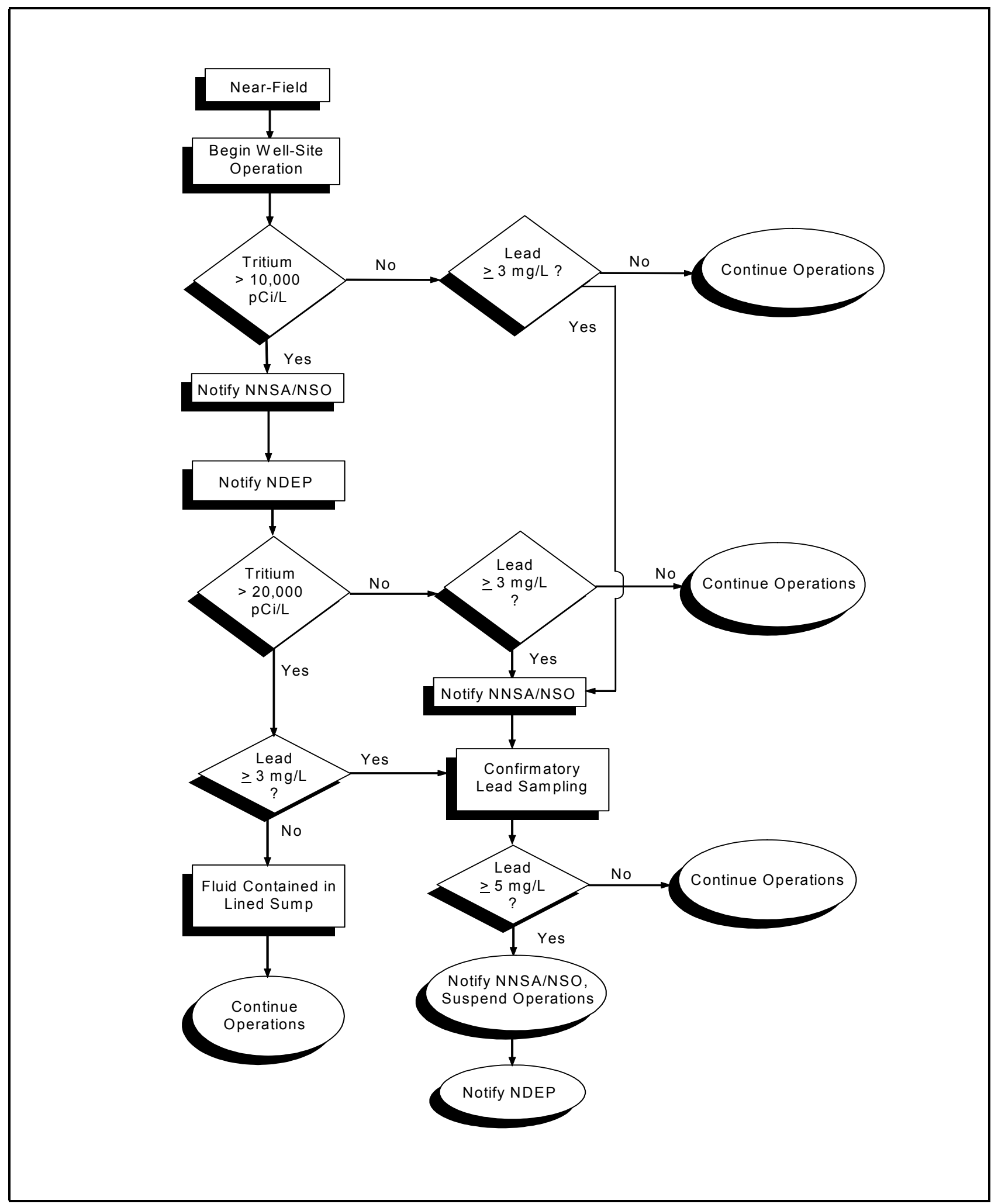

Figure 4-2

Near-Field Monitoring Decision Diagram 
and Recovery Act (RCRA) hazardous waste concentration $(5 \mathrm{mg} / \mathrm{L})$ and may result in the suspension of drilling operations.

\subsubsection{Monitoring}

Fluids generated during near-field operations will be analyzed for lead and tritium while the borehole is being advanced. Such monitoring may be initiated in vadose zone drilling to account for possible prompt injection phenomenon encountered above the groundwater table. Tritium and lead monitoring samples will be collected from the discharge line. The NDEP will be notified via telephone, fax, or e-mail when tritium monitoring levels reach or exceed $10,000 \mathrm{pCi} / \mathrm{L}$. This is a courtesy notification only and will not result in the suspension or alteration of operations. The NNSA/NSO shall be notified immediately when monitoring of tritium and/or lead meets or exceeds the established action level $(20,000 \mathrm{pCi} / \mathrm{L})$. Notification of subsequent monitoring results to the NNSA/NSO and NDEP shall follow established protocol. Monitoring results will be available to NDEP in accordance with Section 7.0 of this document.

\subsubsection{Tritium Monitoring}

During advancement of the borehole, a tritium sample will be collected hourly from the discharge line. Refer to Section 4.2.2 for monitoring requirements during other well-site activities. At a minimum, monitoring samples will be analyzed daily during borehole advancement. The tritium action level under this FMP is $20,000 \mathrm{pCi} / \mathrm{L}$. If this level is exceeded during borehole advancement activities, fluids will be discharged to a lined sump and the site will be considered "radiologically contaminated" from that point forward, until proven otherwise.

\subsubsection{Lead Monitoring}

A lead sample shall be collected from the discharge line once every eight hours while the borehole is being advanced. Monitoring for other well-site activities is discussed in Section 4.2.2. Monitoring samples may be analyzed on site or off site but will, at a minimum, be analyzed daily. Lead may be monitored with a digital voltameter, colorimetric method, or other appropriate method.

Lead is monitored primarily to ensure that the RCRA level for lead $(5 \mathrm{mg} / \mathrm{L})$ is not exceeded. Exceeding the RCRA level for lead may result in the generation of a hazardous or mixed waste in the 
$\operatorname{sump}(\mathrm{s})$. Therefore, the lead monitoring method must be capable of indicating lead at concentrations of $5 \mathrm{mg} / \mathrm{L}$ or less. In order to provide early warning of lead levels approaching the RCRA standard, the level of $3 \mathrm{mg} / \mathrm{L}$ was chosen as the initial decision point for lead monitoring under this FMP. That is, if lead concentrations detected are $3 \mathrm{mg} / \mathrm{L}$ or greater, the confirmatory sampling protocol will be initiated, as described below. The detection of lead at any concentration less than $5 \mathrm{mg} / \mathrm{L}$ will not prompt the shutdown of operations; only a confirmed lead concentration of $5 \mathrm{mg} / \mathrm{L}$ or greater mandates that operations cease (see Figure 4-2).

If a quantitative method is used to monitor lead, the action level for lead is $3 \mathrm{mg} / \mathrm{L}$. If a semiquantitative method is employed, any indication of the presence of lead shall serve as the action level and prompt confirmatory sampling. Throughout the following discussion, the lead "action level" referred to is associated with the RCRA hazardous waste lead level. The process below describes confirmatory sampling to be initiated when the lead action level is exceeded.

If a monitoring sample yields lead concentrations at or above the action level, an additional discharge line sample shall be collected immediately and analyzed. If this confirmatory sample yields lead concentrations less than the action level, the regular 8-hour monitoring schedule shall resume. If the confirmatory sample results in lead concentrations at or above the action level, a composite sample shall be collected immediately from the active sump. The first sump sample shall be analyzed for lead. If the sump sample results fall below the action level, regular 8-hour discharge monitoring shall resume. If the sump sample yields lead levels at or above the action level, drilling operations shall cease and a composite sump sample shall be obtained for laboratory analysis.

\subsubsection{Fluid Management Decision Criteria}

The fluid management decision criteria in Table 4-1 are used to determine the options for final fluid disposition. These criteria are based on the NDWS. Using Offsites Project historical knowledge, the following parameters were selected for establishing fluid quality relative to the NDWS: arsenic, barium, cadmium, chromium, lead, mercury, selenium, silver, tritium, gross alpha, and gross beta. Fluid management decision criteria indicate the thresholds at which fluid disposal decisions are made. The decision criteria are based on the concentration of dissolved constituents. Samples collected in accordance with the sump sampling program will be analyzed for total and dissolved RCRA metals, 
Table 4-1

Fluid Management Decision Criteria Limits

\begin{tabular}{|c|c|c|}
\hline FMP Parameters & $\begin{array}{c}\text { RCRA Levels } \\
(\mathbf{m g} / \mathbf{L})\end{array}$ & $\begin{array}{c}\text { NDWS Standard } \\
(\mathbf{m g} / \mathbf{L})^{\mathbf{a}}\end{array}$ \\
\hline \hline Arsenic & 5.0 & 0.010 \\
\hline Barium & 100.0 & 2 \\
\hline Cadmium & 1.0 & 0.005 \\
\hline Chromium & 5.0 & 0.100 \\
\hline Lead & 5.0 & 0.015 \\
\hline Selenium & 1.0 & 0.050 \\
\hline Silver & 5.0 & 0.100 \\
\hline Mercury & 0.2 & 0.002 \\
\hline Gross Alpha & N/A & $15 \mathrm{pCi} / \mathrm{L}$ \\
\hline Gross Beta & N/A & $50 \mathrm{pCi} / \mathrm{L}$ \\
\hline Tritium & N/A & $20,000 \mathrm{pCi} / \mathrm{L}$ \\
\hline
\end{tabular}

${ }^{a}$ Limit for discharge to the ground surface

gross alpha, gross beta, and tritium (see Table 4-2). Only the dissolved metals results will be compared with Table 4-1 limits when making fluid disposal decisions.

The NDWS criteria limits represent the maximum constituent concentrations below which fluids may be discharged to the ground surface. That is, if all radiological parameters and dissolved metals in Table 4-1 are less than the NDWS, fluids may be discharged directly to the ground surface.

\subsubsection{Sump Sampling Program}

The primary purpose of this sampling program is to determine final fluid disposition. The collection of samples for laboratory analysis applies to fluids contained or stored in sumps and infiltration basins. The analytical results received from the laboratory are compared to the limits in Table 4-1 in order to allow the discharge of fluids to either an infiltration basin/area or the ground surface.

If a sump or infiltration basin is used to contain drilling fluids from an investigation activity, a sump sample shall be collected and analyzed to determine proper disposition of the sump fluids. The primary purpose of these samples is to characterize the contained fluids. While fluids are being added to the sumps or infiltration basins, as during borehole advancement or well completion, a sample does 
Table 4-2

\section{Analytical Laboratory Requirements for Fluid Management Samples}

(Page 1 of 2)

\begin{tabular}{|c|c|c|c|c|c|c|c|}
\hline Parameter & Analytical Method ${ }^{a}$ & Container Type & Preservative $^{c}$ & $\begin{array}{c}\text { Maximum } \\
\text { Holding } \\
\text { Time }^{\mathrm{d}}\end{array}$ & $\begin{array}{l}\text { Reporting Detection } \\
\text { Limit (RDL) }\end{array}$ & $\begin{array}{l}\text { RCRA } \\
\text { Levels }\end{array}$ & $\begin{array}{c}\text { Nevada Drinking Water } \\
\text { Standards } \mathbf{s}^{f}\end{array}$ \\
\hline $\begin{array}{l}\text { Total Metals: } \\
\text { Arsenic } \\
\text { Barium } \\
\text { Cadmium } \\
\text { Chromium } \\
\text { Lead } \\
\text { Selenium } \\
\text { Silver } \\
\text { Mercury }\end{array}$ & $\begin{array}{l}\text { SW-846 6010B } \\
\text { SW-846 6010B } \\
\text { SW-846 6010B } \\
\text { SW-846 6010B } \\
\text { SW-846 6010B } \\
\text { SW-846 6010B } \\
\text { SW-846 6010B } \\
\text { SW-846 7470A }\end{array}$ & $\begin{array}{l}\text { (1) 1-liter } \\
\text { polyethylene or } \\
\text { amber glass }\end{array}$ & $\begin{array}{c}\mathrm{HNO}_{3}{ }^{9} \text { to } \mathrm{pH}<2, \\
\text { Cool to } 4 \mathrm{EC} \pm 2 \mathrm{EC}\end{array}$ & $\begin{array}{l}180 \text { Days } \\
28 \text { Days }\end{array}$ & $\begin{array}{c}0.01 \mathrm{mg} / \mathrm{L} \\
0.2 \mathrm{mg} / \mathrm{L} \\
0.005 \mathrm{mg} / \mathrm{L} \\
0.01 \mathrm{mg} / \mathrm{L} \\
0.003 \mathrm{mg} / \mathrm{L} \\
0.005 \mathrm{mg} / \mathrm{L} \\
0.01 \mathrm{mg} / \mathrm{L} \\
0.0002 \mathrm{mg} / \mathrm{L}\end{array}$ & $\begin{array}{l}5.0 \mathrm{mg} / \mathrm{L} \\
100 \mathrm{mg} / \mathrm{L} \\
1.0 \mathrm{mg} / \mathrm{L} \\
5.0 \mathrm{mg} / \mathrm{L} \\
5.0 \mathrm{mg} / \mathrm{L} \\
1.0 \mathrm{mg} / \mathrm{L} \\
5.0 \mathrm{mg} / \mathrm{L} \\
0.2 \mathrm{mg} / \mathrm{L}\end{array}$ & $\begin{array}{c}0.01 \mathrm{mg} / \mathrm{L} \\
2.0 \mathrm{mg} / \mathrm{L} \\
0.005 \mathrm{mg} / \mathrm{L} \\
0.1 \mathrm{mg} / \mathrm{L} \\
0.015 \mathrm{mg} / \mathrm{L} \\
0.05 \mathrm{mg} / \mathrm{L} \\
0.1 \mathrm{mg} / \mathrm{L} \\
0.002 \mathrm{mg} / \mathrm{L}\end{array}$ \\
\hline $\begin{array}{l}\text { Dissolved Metals: } \\
\text { Arsenic } \\
\text { Barium } \\
\text { Cadmium } \\
\text { Chromium } \\
\text { Lead } \\
\text { Selenium } \\
\text { Silver } \\
\text { Mercury }\end{array}$ & $\begin{array}{l}\text { SW-846 6010B } \\
\text { SW-846 6010B } \\
\text { SW-846 6010B } \\
\text { SW-846 6010B } \\
\text { SW-846 6010B } \\
\text { SW-846 6010B } \\
\text { SW-846 6010B } \\
\text { SW-846 7470A }\end{array}$ & $\begin{array}{l}\text { (1) 1-liter } \\
\text { polyethylene or } \\
\text { amber glass }\end{array}$ & $\begin{array}{c}\text { Field Filtration } \\
\mathrm{HNO}_{3} \text { to } \mathrm{pH}<2, \\
\text { Cool to } 4 \mathrm{EC} \pm 2 \mathrm{EC} \\
\text { OR } \\
\mathrm{Lab}^{2} \text { Filtration, } \\
\mathrm{HNO}_{3} \text { to } \mathrm{pH}<2, \\
\text { Cool to } 4 \mathrm{EC} \pm 2 \mathrm{EC}\end{array}$ & $\begin{array}{l}180 \text { Days } \\
28 \text { Days }\end{array}$ & $\begin{array}{c}0.01 \mathrm{mg} / \mathrm{L} \\
0.2 \mathrm{mg} / \mathrm{L} \\
0.005 \mathrm{mg} / \mathrm{L} \\
0.01 \mathrm{mg} / \mathrm{L} \\
0.003 \mathrm{mg} / \mathrm{L} \\
0.005 \mathrm{mg} / \mathrm{L} \\
0.01 \mathrm{mg} / \mathrm{L} \\
0.0002 \mathrm{mg} / \mathrm{L}\end{array}$ & $\begin{array}{l}5.0 \mathrm{mg} / \mathrm{L} \\
100 \mathrm{mg} / \mathrm{L} \\
1.0 \mathrm{mg} / \mathrm{L} \\
5.0 \mathrm{mg} / \mathrm{L} \\
5.0 \mathrm{mg} / \mathrm{L} \\
1.0 \mathrm{mg} / \mathrm{L} \\
5.0 \mathrm{mg} / \mathrm{L} \\
0.2 \mathrm{mg} / \mathrm{L}\end{array}$ & $\begin{array}{c}0.01 \mathrm{mg} / \mathrm{L} \\
2.0 \mathrm{mg} / \mathrm{L} \\
0.005 \mathrm{mg} / \mathrm{L} \\
0.1 \mathrm{mg} / \mathrm{L} \\
0.015 \mathrm{mg} / \mathrm{L} \\
0.05 \mathrm{mg} / \mathrm{L} \\
0.1 \mathrm{mg} / \mathrm{L} \\
0.002 \mathrm{mg} / \mathrm{L}\end{array}$ \\
\hline $\begin{array}{l}\text { Gross Alpha } \\
\text { Gross Beta }\end{array}$ & $\begin{array}{l}\text { EPA } 900.0 \text { or } \\
\text { equivalent }\end{array}$ & $\begin{array}{l}\text { (1) 1-liter } \\
\text { polyethylene }\end{array}$ & $\begin{array}{c}\text { Field Filtration } \\
\mathrm{HNO}_{3} \text { to } \mathrm{pH}<2 \\
\text { OR } \\
\mathrm{Lab}^{2} \text { Filtration, } \\
\mathrm{HNO}_{3} \text { to } \mathrm{pH}<2\end{array}$ & 180 Days & $\begin{array}{r}10 \mathrm{pCi} / \mathrm{L}^{\mathrm{i}} \\
<15 \mathrm{pCi} / \mathrm{L}\end{array}$ & $\begin{array}{l}N / A \\
N / A\end{array}$ & $\begin{array}{l}15 \mathrm{pCi} / \mathrm{L} \\
50 \mathrm{pCi} / \mathrm{L}\end{array}$ \\
\hline Tritium & $\begin{array}{l}\text { EPA } 906.0 \text { or } \\
\text { equivalent }\end{array}$ & $\begin{array}{l}\text { (1) } 500-\mathrm{mL} \\
\text { amber glass }\end{array}$ & $\begin{array}{l}\text { Field or Lab } \\
\text { Filtration }\end{array}$ & 180 Days & $1,000 \mathrm{pCi} / \mathrm{L}$ & $\mathrm{N} / \mathrm{A}$ & $20,000 \mathrm{pCi} / \mathrm{L}$ \\
\hline
\end{tabular}




\title{
Table 4-2
}

\section{Analytical Laboratory Requirements for Fluid Management Samples}

(Page 2 of 2)

\author{
anorganic methods taken from EPA Test Methods for Evaluating Solid Waste, $3^{\text {rd }}$ Edition, Parts 1-4, SW-846 (EPA, 1996); radiochemical methods taken from Prescribed Procedures for \\ Measurement of Radioactivity in Drinking Water (EPA, 1980) \\ 'Inorganic requirements taken from EPA Test Methods for Evaluating Solid Waste, $3^{\text {rd }}$ Edition, Parts 1-4, SW-846 (EPA, 1996); radiochemical volume specifications are based on \\ sample compositing requirements \\ Inorganic requirements taken from EPA Contract Laboratory Program Statement of Work for Inorganic Analysis (EPA, 1994) \\ 'Inorganic requirements taken from EPA Contract Laboratory Program Statement of Work for Inorganic Analysis (EPA, 1994) \\ Inorganic requirements taken from EPA Contract Laboratory Program Statement of Work for Inorganic Analysis (EPA, 1994) \\ Nevada Drinking Water Standards \\ ${ }^{9}$ Nitric Acid \\ ${ }^{\text {h}}$ Filtration and preservation, when required, should be performed in the field. If the matrix of the sample makes field filtration too difficult, the sample will be sent to the laboratory for \\ subsequent filtering and preservation. \\ Picocuries per liter \\ EPA $=$ Environmental Protection Agency \\ $\mathrm{HNO}_{3}=$ Nitric Acid \\ $\mathrm{mg} / \mathrm{L}=$ Milligrams per liter \\ $\mathrm{mL}=$ Milliliter \\ $\mathrm{N} / \mathrm{A}=$ Not applicable \\ $\mathrm{pCi} / \mathrm{L}=$ Picocuries per liter \\ RCRA = Resource Conservation and Recovery Act \\ ${ }^{\circ} \mathrm{C}=$ Degrees Celsius
}


not need to be collected. However, once operations that affect containment volume have ceased or a change in fluid containment will occur (e.g., discharging fluids from a lined sump to and from an infiltration basin or from an infiltration basin to the ground surface), a sample must be collected for laboratory analysis. The sample must be collected from the sump or infiltration basins to which fluids were discharged (active sump) and from all sumps or infiltration basins to which fluids may have been transferred in the course of the immediate investigation activity. Samples shall be collected, or the appropriate analytical data obtained, for each containment that contains fluid at a site prior to vacating the site. Contained fluids will be analyzed for the parameters listed in Table 4-2.

\subsubsection{Fluid Disposition}

This section discusses fluid disposition options for fluids that are contained/stored in a lined sump. This FMP allows the discharge of investigation fluids on site when specific fluid criteria are met. The two options for on-site disposal of investigation fluids are (1) an infiltration basin or area, and (2) the ground surface. An infiltration basin is a constructed unlined basin or pit. An infiltration area is a predesignated bounded area on the ground surface within which fluids may be discharged. The "ground surface" refers to the natural or relatively undisturbed condition of an area of surface soil or rock. Decisions on fluid disposition are based on laboratory sample results, as compared to fluid decision criteria. Fluids will not be discharged to an infiltration area or the ground surface from a lined sump if the fluid decision criteria provided in Table 4-1 are not met. The on-site disposal options for fluids stored in lined sumps are:

- Direct discharge to the ground surface. Fluids documented to be equal to or less than NDWS for all required FMP analytical parameters may be discharged to the ground surface. Caution shall be taken to ensure that erosion is controlled.

- Discharge to an infiltration basin/area. Fluids documented to be less than NDWS for all required FMP analytical parameters may be discharged to an infiltration basin/area.

If fluids do not meet the fluid decision criteria for discharge/disposal on site, then fluid disposal options include (1) on-site containment in lined sumps, or (2) transport for disposal off site. The criteria for these options are as follows:

- On-site containment in a lined sump. Fluids documented to contain RCRA metals below hazardous waste limits found in the most recent version of Title 40 Code of Federal Regulations (CFR) Part 261.24 (RCRA standards) [CFR, 2004] and radiological parameters greater than $20 \times$ NDWS will be allowed to evaporate in lined sumps on site. 
Alternatively, these fluids may be transported off site via portable tanks to another lined sump for storage or transported to a storage area on the Nevada Test Site (NTS) or a permitted commercial treatment, storage, and disposal facility.

- Transportation to the NTS or a treatment, storage, and disposal facility. Fluids documented to contain any RCRA metal above its respective hazardous waste limit found in the most recent version of 40 CFR 261.24 (RCRA standards) [CFR, 2004] would result in the suspension of operations. These fluids would be managed as hazardous (or mixed) waste in accordance with the most current version of the State of Nevada hazardous waste regulations and applicable DOE orders. The NNSA/NSO and the NDEP will be notified immediately if fluids are documented to be hazardous or mixed waste. The fluids may be pumped from the lined sumps and transported to an appropriate storage area on the NTS, or may be transported directly to a permitted commercial treatment, storage, or disposal facility.

Figure 4-3 illustrates the general decision flow process for the disposal of fluids under this FMP. The appropriate fluid disposal option will be chosen based on a comparison of the appropriate laboratory analytical data with the fluid management decision criteria specific to each option. As indicated, the concentrations of fluid management parameters outlined in Table 4-1 shall not exceed NDWS if the fluids are to be discharged to an infiltration basin/area. Fluids intended for discharge to the ground surface must not exceed NDWS.

\subsection{Other Well-Site Activities}

Other well-site activities include those which encounter subsurface formations that were previously drilled through or contacted in some way. Examples of other well-site activities that typically occur without advancement of the borehole include cleaning and conditioning the borehole, circulation of the borehole, fishing and wash-over operations, well completion operations such as casing and stemming of annular materials, well development, testing, and periodic sampling events. Well completion designs and associated well construction activities will vary depending on well-specific objectives and may include the setting of intermediate casing; the running of a completion string to a specified depth; and/or the isolation of productive zones with gravel, cement, packers, and sliding sleeves. Other activities may be conducted within a discrete time period (e.g., a one-day well sampling event) or over a span of time (e.g., a series of well purging and testing activities that span months). 


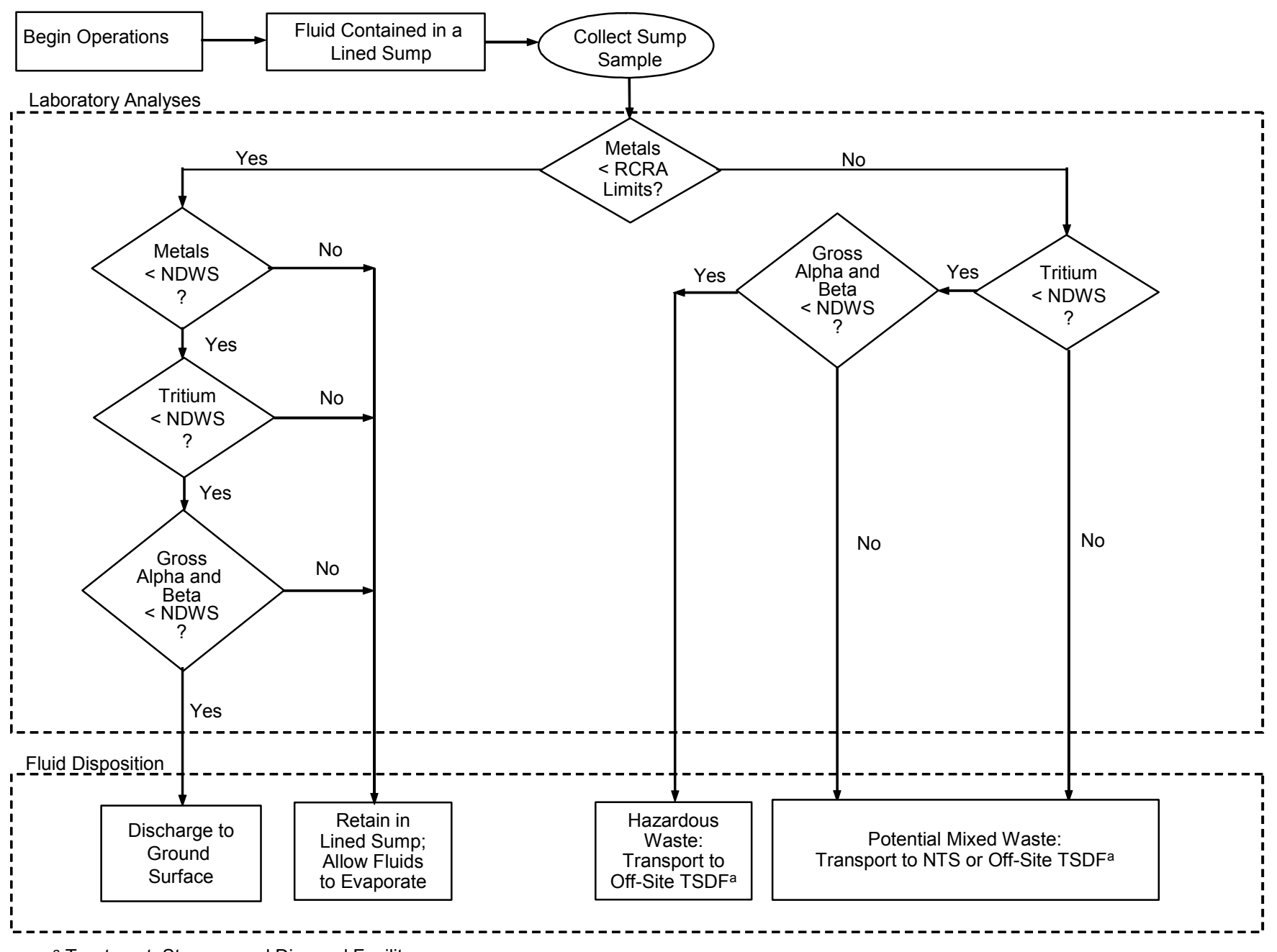

a Treatment, Storage, and Disposal Facility

Figure 4-3

Decision Diagram for Fluid Disposal 


\subsubsection{Fluid Containment}

Fluid containment options during other well-site activities operating under the near-field strategy will typically be the same as those described in Section 4.1.1. Lined sumps used during borehole advancement may be used for fluid containment during well development, testing, and periodic sampling activities.

If well-site conditions have changed from near-field to far-field, alternate fluid containment options will be available during other well-site activities, to include discharge to an infiltration basin/area or to the ground surface (see Section 6.0). The NNSA/NSO will notify NDEP of any change in well-site operation strategy.

\subsubsection{Monitoring}

The primary difference between monitoring during borehole advancement and during other well-site activities is the frequency of monitoring sample collection. In a near-field scenario during other well-site activities, a minimum of one tritium sample and one lead sample will be collected daily from the discharge line and analyzed weekly at a minimum. The results of each sample will be used to make decisions regarding fluid containment and/or the progression of investigation operations. Refer to Section 4.1.2 for detailed information on tritium and lead monitoring in a near-field scenario.

\subsubsection{Fluid Management Decision Criteria}

The fluid management decision criteria in Table 4-1 are to be used to determine the options for final disposition of fluids generated during other well-site activities. Refer to Section 4.1.3 for further detail.

\subsubsection{Sump Sampling Program}

The sump sampling program for other well-site activities is the same as that during borehole advancement. A sump sample shall be collected once fluid producing operations have ceased. For example, in a near-field situation, if a well is being purged in preparation for periodic sampling, fluids may be discharged to a lined sump. A sump sample will be collected from the sump where fluids were discharged (active sump) and from all sumps where fluids may have been transferred to during 
the course of the activity. Sump samples shall be collected, or appropriate analytical data obtained, for each sump that contains fluid at a site prior to vacating the site. Sump fluids will be analyzed for the parameters listed in Table 4-2.

\subsubsection{Fluid Disposition}

The same decision process for fluid disposition of near-field drilling fluids is to be implemented for fluids generated during other well-site activities. Refer to Section 4.1 .5 for further detail. 


\subsection{Far-Field Fluid Management Strategy}

At far-field wells, it is not expected that radioactive constituents or metals contamination from underground testing will be encountered in excess of NDWS (see Table 4-1). No far-field wells constructed to date have exceeded fluid quality parameters for discharging fluids to a constructed infiltration basin/area. In fact, most far-field wells have met fluid quality parameters for discharging fluids directly to the ground surface. In the far-field scenario, tritium will be used as the contaminant indicator and will be monitored in accordance with the following sections.

\subsection{Well Drilling Activities}

Drilling activities that advance the borehole involve only those that cut or disturb new subsurface formation(s). Presumably, groundwater and rock cuttings generated as part of these operations are from geologic formations that are uncharacterized with regard to their chemical and radiological nature. Rock cuttings generated during the drilling activities will be contained with the fluid following the far-field strategy. The cuttings will then be managed under the waste management plan that will be implemented during the site restoration.

\subsubsection{Fluid Containment}

Under a far-field strategy, fluids may be discharged directly from the well to the ground surface, an unlined infiltration basin/area, a lined sump, or aboveground containment (e.g., Baker tank, drum). An infiltration basin is a constructed unlined basin or pit. An infiltration area is a predesignated bounded area within which fluids may be discharged.

The type of fluid containment required will be based on available process knowledge and identified in the Well-Site Operation Strategy letter approved by the NDEP (see Section 3.0). In a typical far-field scenario, two infiltration basins may be constructed. An equalizing pipe may be constructed between the basins to allow for the transfer of fluids from one basin to the other. An overflow pipe may be constructed in one of the infiltration basins to allow for discharge to the ground surface. Figure 5-1 offers an example of a typical far-field fluid containment configuration. In some situations, one infiltration basin may be lined as a contingency in the event that monitoring identifies fluids that do not meet fluid management criteria (refer to Transition Strategy in Section 6.0). 


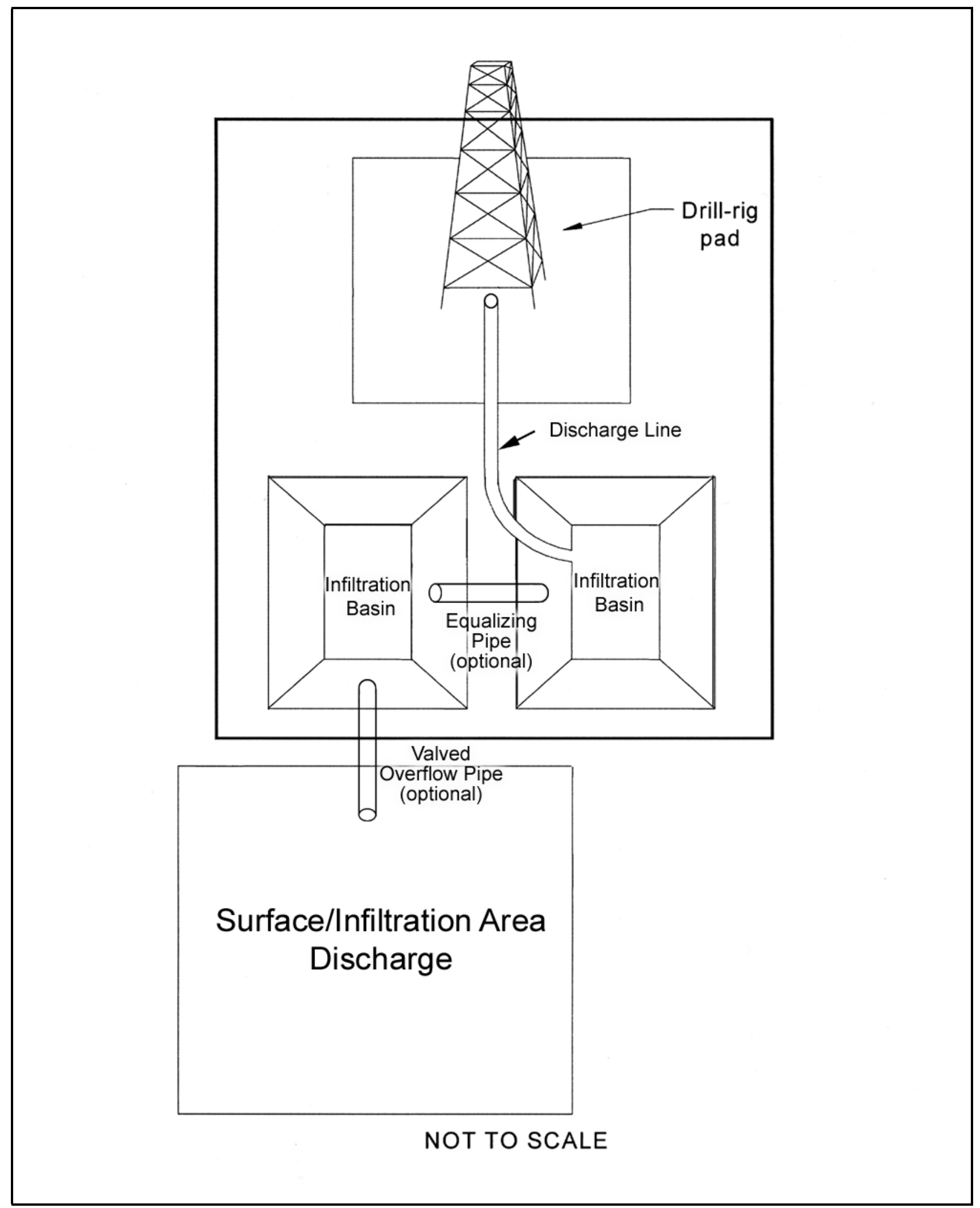

Figure 5-1

Far-Field Site Layout 


\subsubsection{Monitoring Program}

The monitoring program supports the daily management of fluids produced during an investigation activity. This program is based on the use of tritium as a contamination indicator to make decisions regarding fluid containment and/or the progression of investigation operations.

Based on its physical and chemical properties, tritium has been chosen as the indicator for radioactive contamination. Tritium is a radioactive isotope that is readily transported in groundwater and provides the earliest detection of groundwater contamination resulting from underground testing.

Monitoring results are not used to support final fluid disposition decisions; rather, monitoring results prompt daily operational decisions. Figure 5-2 outlines the decision points in the monitoring program for far-field well sites under this FMP. The NNSA/NSO shall be notified immediately when monitoring of tritium meets or exceeds the established action level. Notification of subsequent monitoring results to the NNSA/NSO and NDEP shall follow established protocol.

\subsubsection{Monitoring}

Based on previous wells drilled at the Offsites Project locations, chemical and/or radiological contamination from underground testing in a well operating under a far-field strategy is not likely to be encountered. The potential for lead from underground testing to be present in drilling fluids in the far-field is remote. Lead is not monitored under a far-field strategy. However, due to the ability of tritium to move with groundwater, tritium is monitored under the far-field strategy. The NNSA/NSO will notify NDEP via telephone, fax, or e-mail when tritium monitoring levels trend toward or consistently exceed $10,000 \mathrm{pCi} / \mathrm{L}$. This is a courtesy notification only and may result in the suspension or alteration of operations.

\subsubsection{Tritium Monitoring}

While advancing the borehole at a far-field site, a tritium sample will be collected every $20 \mathrm{ft}$ of advance or two hours, whichever occurs first at the discharge line. Tritium monitoring for other well-site activities is discussed in Section 5.2.2. Monitoring samples will be analyzed daily at a minimum. Figure 5-2 outlines the decision points in the monitoring program for far-field well sites 


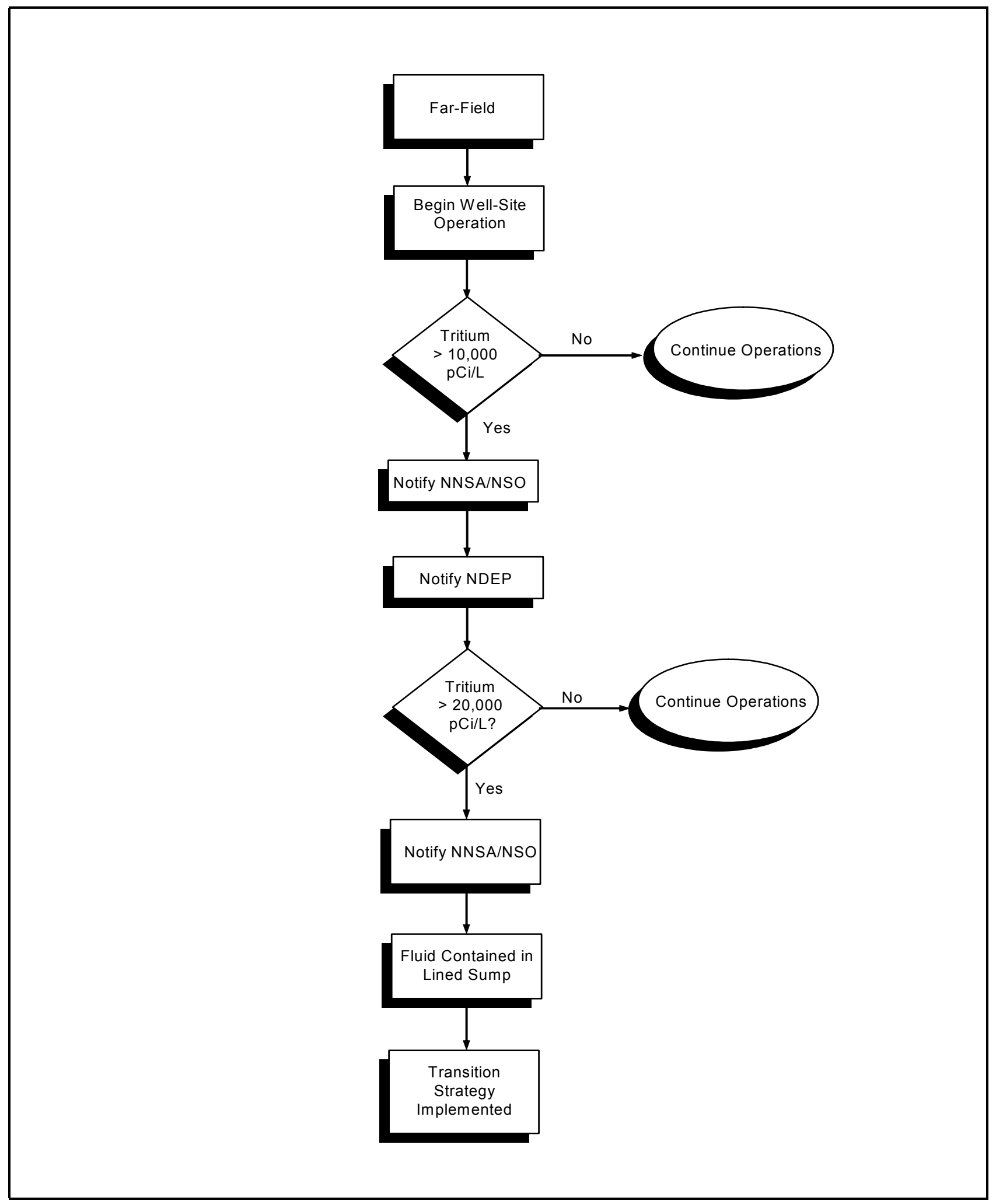

Figure 5-2

Far-Field Monitoring Decision Diagram 
under this FMP. Further reduction or elimination of tritium monitoring shall be based on process knowledge and approval from NNSA/NSO and NDEP.

\subsection{Other Well-Site Activities}

Other well-site activities include those which encounter subsurface formations that were previously drilled through or contacted in some way. Examples of other well-site activities that typically occur without advancement of the borehole include cleaning and conditioning the borehole, circulation of the borehole, fishing and wash-over operations, well completion operations such as casing and stemming of annular materials, well development, testing, and periodic sampling events. Well completion designs and associated well construction activities will vary depending on well-specific objectives and may include the setting of intermediate casing; the running of a completion string to a specified depth; and/or the isolation of productive zones with gravel, cement, packers, and sliding sleeves. Other activities may be conducted within a discrete time period (e.g., a one-day well sampling event) or over a span of time (e.g., a series of well purging and testing activities that span months).

\subsubsection{Fluid Containment}

Fluid containment options during other well-site activities operating under the far-field strategy will typically be the same as those described in Section 5.1.1.

\subsubsection{Monitoring}

During other well-site activities, a tritium sample will be collected once every day at the discharge line. Monitoring samples may be analyzed on site or off site but will be analyzed weekly at a minimum. Further reduction or elimination of tritium monitoring shall be based on process knowledge and approval from NNSA/NSO and NDEP. 


\subsection{Transition Strategy}

In the event that monitoring at a designated far-field well site reveals tritium concentrations that exceed the fluid management criteria for near-field wells (i.e., concentrations greater than $20,000 \mathrm{pCi} / \mathrm{L}$ ), operations shall cease immediately and the NNSA/NSO notified. The following transition strategy may be employed to transition well-site operations from a far-field strategy to a near-field strategy.

In essence, the well site will change to a near-field site, with tritium being monitored hourly and lead being monitored every eight hours. A minimum of one single-lined sump may be constructed to contain fluids that exceed the tritium action level. The action levels and subsequent actions taken when these levels are exceeded remain the same as in the near-field strategy. The NNSA/NSO shall be notified immediately when monitoring of tritium and/or lead meets or exceeds the established action level. Notification of subsequent monitoring results to the NNSA/NSO and NDEP shall follow established protocol. 


\subsection{Reporting Requirements}

The NNSA/NSO shall comply with the following reporting requirements for all investigation activities covered under this FMP, which are undertaken in support of the Offsites Project:

- Fluid Release Reporting. The NDEP shall be notified in the event that fluids in excess of NDWS limits, as defined by this FMP, are discharged into an infiltration basin, infiltration area, or beyond the confines of a lined sump in volumes greater than 1 cubic meter (264 gallons). Such notification must be provided by telephone prior to the end of the next business day following verification of the incident. Telephone notification shall be followed by a written report which includes elements described in spill reporting regulations within ten calendar days.

- Hazardous or Mixed Waste Generation. The NDEP will be notified immediately if laboratory results indicate that mixed or hazardous waste has been generated in a lined sump or infiltration basin. Nonemergency actions that constitute deviations to this FMP will be reported to the NDEP prior to implementation of the action. Emergency actions that are taken that constitute deviations to this FMP will be reported orally to NDEP within 24 hours of implementation of the action, and a written report will be provided to NDEP within 10 working days of the action.

- Well-Site Operation Strategy Letter. The NNSA/NSO will submit a Well-Site Operation Strategy letter to NDEP for approval before well-site activities begin.

- Well-Site Activity Reporting (Morning Reports). The synopsis of well-site activities occurring within a 24-hour period (i.e., the morning report) shall be transmitted (fax or electronic mail) to the NDEP each day for all activities covered under this FMP. Fluid releases not reportable under "Fluid Release Reporting" above will be discussed in these morning reports.

All correspondence to the NDEP shall be addressed to:
Christine Andres
Nevada Division of Environmental Protection
Bureau of Federal Facilities
1771 E. Flamingo Road, Suite 121-A
Las Vegas, NV 89119

All field and laboratory data generated in support of Offsites Project well-construction activities will be archived and made available for inspection by the NDEP upon request. The following data will be 
generated and retained on file. This data shall be made available to the appropriate NDEP staff for inspection upon request:

- Legible copies of daily drilling progress reports and records of daily well-site activities.

- Volumetric measurements of fluids generated during each stage of well construction.

- Records of make-up water delivery and usage during each stage of well construction.

- On-site fluid monitoring data.

- Laboratory analytical data with supplemental quality assurance/quality control and chain of custody records.

- Records of process materials (e.g., cement, grout, casing, screens, packing, drilling fluids) and drilling additive usage, and equipment decontamination. 


\subsection{References}

CFR, see Code of Federal Regulations.

Code of Federal Regulations. 2004. 40 CFR Part 261.24, "Toxicity Characteristic." Washington, DC: U.S. Government Printing Office.

DRI, see Desert Research Institute.

Desert Research Institute. 1988. CERCLA Preliminary Assessment of DOE's Nevada Operations Office Nuclear Weapons Testing Areas. Las Vegas, NV.

EPA, see U.S. Environmental Protection Agency.

FFACO, see Federal Facility Agreement and Consent Order.

Federal Facility Agreement and Consent Order. 1996 (as amended). Agreed to by the State of Nevada, the U.S. Department of Energy, and the U.S. Department of Defense.

Federal Register. 1962b. Public Land Order 2834, "Correcting Certain Public Land Orders; Amending Public Land Order No. 2771 of September 6, 1962,” Doc. 62-12191, 10 December. Washington, DC: U.S. Government Printing Office.

U.S. Environmental Protection Agency. 1980. Prescribed Procedures for Measurement of Radioactivity in Drinking Water. Washington, DC.

U.S. Environmental Protection Agency. 1994. EPA Contract Laboratory Program Statement of Work for Inorganic Analysis. Washington, DC.

U.S. Environmental Protection Agency. 1996. Test Methods for Evaluating Solid Waste, $3^{\text {rd }}$ Edition, SW-846. Washington, DC. 


\section{Appendix A}

\section{Nevada Division of Environmental Protection Comments}




\begin{tabular}{|c|c|c|c|}
\hline \multicolumn{3}{|c|}{$\begin{array}{l}\text { 1. Document Title/Number Fluid Management Plan for CAU 447: Project Shoal Area, } \\
\text { Subsurface, Nevada }\end{array}$} & ocument Date_May 2005 \\
\hline \multicolumn{3}{|c|}{ 3. Revision Number Draft } & 4. Originator/Organization $\underline{\mathrm{SNJV}}$ \\
\hline \multicolumn{3}{|c|}{ 5. Responsible DOE/NV ERP Project Mgr. } & 6. Date Comments Due \\
\hline \multicolumn{4}{|l|}{ 7. Review Criteria } \\
\hline \multicolumn{3}{|c|}{ 8. Reviewer/Organization/Phone No. _ NDEP - Chief, BoFF, (702) 486-2874 } & 9. Reviewer: Tim Murphy \\
\hline $\begin{array}{l}\text { 10. Comment } \\
\text { Number/Location }\end{array}$ & $\begin{array}{l}11 . \\
\text { Type }^{\mathrm{a}}\end{array}$ & 12. Comment/Rationale & 13. Comment Response \\
\hline $\begin{array}{l}1 . \\
\text { Page 2, Figure } \\
1-1\end{array}$ & Specific & $\begin{array}{l}\text { The current Figure 1-1 should be replaced with a legible Figure } \\
\text { 1-1. The Figure supplied in the Draft Plan is illegible. }\end{array}$ & $\begin{array}{l}\text { Figure } 1-1 \text { was replaced with } \\
\text { a legible figure. }\end{array}$ \\
\hline $\begin{array}{l}2 . \\
\text { Throughout }\end{array}$ & General & $\begin{array}{l}\text { The NDEP has the following comment in regards to the fluid } \\
\text { management decision criteria and fluid disposition. Please not } \\
\text { that this comment applies only to management of fluids } \\
\text { generated from the well-construction, development, } \\
\text { hydrologic/aquifer testing, and sampling activities at the Projec } \\
\text { Shoal Area. Any fluids discharged directly to an unlined sump } \\
\text { infiltration basin/area, or ground surface must not exceed the } \\
\text { respective Nevada Drinking Water Standard (NDWS) for all th } \\
\text { parameters listed in Table } 4-1 \text {. Any fluids containing Plan } \\
\text { parameters in excess of a respective NDWS should be } \\
\text { discharged to a lined sump. Please correct the relevant } \\
\text { paragraphs and Figures in the Plan to reflect these fluid decisior } \\
\text { criteria. }\end{array}$ & $\begin{array}{l}\text { Comments were incorporated } \\
\text { with changes to the associated } \\
\text { tables and verbiage. All } \\
\text { references to possible } \\
\text { contaminants and action } \\
\text { levels were changed to reflect } \\
\text { the NDWS and eliminated } \\
\text { reference to } 5,10 \text {, and } 20 \\
\text { times NDWS. }\end{array}$ \\
\hline
\end{tabular}




\title{
Library Distribution List
}

\author{
$\underline{\text { Copies }}$ \\ U.S. Department of Energy \\ 1 (Uncontrolled) \\ National Nuclear Security Administration \\ Nevada Site Office \\ Technical Library \\ P.O. Box 98518, M/S 505 \\ Las Vegas, NV 89193-8518 \\ U.S. Department of Energy \\ 1 (Uncontrolled, electronic copy) \\ Office of Scientific and Technical Information \\ P.O. Box 62 \\ Oak Ridge, TN 37831-0062 \\ Southern Nevada Public Reading Facility \\ 2 (Uncontrolled) \\ c/o Nuclear Testing Archive \\ P.O. Box 98521, M/S 400 \\ Las Vegas, NV 89193-8521 \\ Manager, Northern Nevada FFACO \\ 1 (Uncontrolled) \\ Public Reading Facility \\ c/o Nevada State Library \& Archives \\ Carson City, NV 89701-4285
}

